\title{
The high potential of Pelargonium roseum plant for phytoremediation of heavy metals
}

\author{
Majid Mahdieh • Mojtaba Yazdani • Shahla Mahdieh
}

Received: 30 July 2012 / Accepted: 8 February 2013 /Published online: 21 February 2013

(C) The Author(s) 2013. This article is published with open access at Springerlink.com

\begin{abstract}
The major objective of this investigation was to evaluate the potential of scented geraniums, Pelargonium roseum, to uptake and accumulate heavy metals nickel $(\mathrm{Ni})$, cadmium $(\mathrm{Cd})$, or lead $(\mathrm{Pb})$. For this, plants were grown in an artificial soil system and exposed to a range of metal concentrations over a 14-day treatment period. Then, metals from the entire biomass were extracted. The results showed that scented geranium plants accumulated in excess of $20,055 \mathrm{mg}$ of $\mathrm{Ni} \mathrm{kg}-1$ dry weight (DW) of root and 10,889 $\mathrm{mg}^{\text {of } \mathrm{Ni} \mathrm{kg}^{-1} \mathrm{DW}}$ of shoot, and in excess of $86,566 \mathrm{mg}$ of $\mathrm{Pb} \mathrm{kg}^{-1} \mathrm{DW}$ for roots and 4,416 mg of $\mathrm{Pb} \mathrm{kg}^{-1} \mathrm{DW}$ for shoots within 14 days. Also, the uptake and accumulation of cadmium in roots of scented geranium plants increased with the exposure at low $\left(250,500 \mathrm{mgL}^{-1}\right)$ and medium level $\left(750 \mathrm{mgL}^{-1}\right)$ followed by a decline at the highest level $\left(1,000 \mathrm{mgL}^{-1}\right)$. The highest accumulation in roots
\end{abstract}

M. Mahdieh $(\bowtie)$

Department of Biology, Faculty of Science,

Arak University,

Arak 38156-8-8349, Iran

e-mail: m-mahdiyeh@araku.ac.ir

\section{Yazdani}

Department of Biology, School of Science, Islamic Azad University, Ashtian Branch,

Ashtian, Iran

S. Mahdieh

Department of Biology,

Pyam Noor University, Najafabad Branch,

Najafabad, Isfahan, Iran $\left(31,267 \mathrm{mgkg}^{-1} \mathrm{DW}\right)$ was observed in $750 \mathrm{mgL}^{-1}$ cadmium treatment. In the shoots of scented geraniums, the highest amount of metal accumulation $\left(1,957 \mathrm{mgkg}^{-1}\right.$ DW) was detected at 750 and $1,000 \mathrm{mgL}^{-1}$ of cadmium in the culture solution. Finally, since the high concentrations of $\mathrm{Ni}$ or $\mathrm{Pb}$ accumulated in shoots of scented geranium has far exceeded $0.1 \% \mathrm{DW}$ and for $\mathrm{Cd}$ has far exceeded $0.01 \% \mathrm{DW}, P$. roseum is a new hyperaccumulator species for these metals and can be used in phytoremediation industry.

Keywords Hyperaccumulator · Heavy metals · Pelargonium roseum $\cdot$ Phytoremediation $\cdot$ Scented geranium

\section{Introduction}

Sites where soils are contaminated with heavy metals are commonly found as a result of activities such as metal mining and refining, specific industrial processes or the long-term disposal of wastes such as sewage sludge. Elevated concentrations of heavy metals in soils may cause phytotoxicity, direct hazard to human health, indirect effects due to transmission through the food chain or contamination of ground or surface waters.

Clean-up technologies have been developed for the removal of heavy metals (Luo 2009), but often these are expensive or have some environmentally deleterious consequences. Soil washing techniques, both in 
situ and ex situ, aim to remove metals from soil but have detrimental effects on their physical and biological properties and result in a waste product with a high metal content, which itself requires disposal.

Phytoremediation, the use of plants to reduce the risk associated with heavy metal contaminated soils, is now being actively investigated as a low-cost option that causes no deterioration in soil quality. The idea originated from the identification of hyperaccumulator plants, which can take up large amounts of heavy metals and accumulate high concentrations in their above ground tissues with no adverse effects on growth (Baker et al. 1994; Chaney et al. 1997; Reeves and Baker 2000).

Currently, the defining plant tissue concentrations for hyperaccumulation are $\mathrm{Cd}>100 \mathrm{mgkg}^{-1}$; Co, $\mathrm{Cu}, \mathrm{Ni}, \mathrm{Pb}>1,000 \mathrm{mgkg}^{-1}$; $\mathrm{Mn}, \mathrm{Zn}>10,000 \mathrm{mg}$ $\mathrm{kg}^{-1}$. However, plants with such a large accumulation of heavy metals typically produce relatively small amounts of biomass and have no economic value (Gleba et al. 1999). Thus, identification of new plant species with a high biomass and a robust growth habit, coupled with ability to tolerate and accumulate multiple metals, has become an important aspect of phytoremediation.

The overall objective of the current investigation was to evaluate the potential of the scented geranium plants, Pelargonium roseum, to uptake and accumulate major metal pollutants, nickel, cadmium, and lead from growth substrate.

\section{Materials and methods}

Preparation of test material

Scented geranium rooted cuttings (Pelargonium roseum) were used for all experiments in this study. Cuttings of scented geraniums made from greenhouse-grown plants were rooted in plastic pots containing approximately $100 \mathrm{~g}$ of wellwashed coarse vermiculite.

Plants (one plant in each pot) were placed in plastic saucers (three pots in each saucer, two saucers per treatment, and six plants per treatment). The plants were grown in a greenhouse equipped with supplementary lighting (16/8 h photoperiod; 15 Klux) and controlled temperature $\left(18-22{ }^{\circ} \mathrm{C}\right)$ for 45 days with irrigation and fertilization.
Metal exposure

During the treatment period (14 days), the rooted cuttings were treated with $50 \mathrm{~mL}$ of half-strength Hoagland's solution (Hoagland and Arnon 1950) devoid of phosphates and sulphates but supplemented with the metal salt. The metal treatments were applied individually and provided as nitrate: $0,250,500,750$, $1,000 \mathrm{mgL}^{-1} \mathrm{Ni}\left(\mathrm{NO}_{3}\right)_{2} \cdot 4 \mathrm{H}_{2} \mathrm{O}$ or $\mathrm{Cd}\left(\mathrm{NO}_{3}\right)_{2} \cdot 4 \mathrm{H}_{2} \mathrm{O}$ and 0, 500, 1,000, 1,500, 2,000, 2,500 $\mathrm{mgL}^{-1} \mathrm{~Pb}\left(\mathrm{NO}_{3}\right)_{2}$, and the $\mathrm{pH}$ of the metal solutions was adjusted to 6.0 6.5. The solutions were applied in the saucers and repeated at 24-h intervals, over the 14-day treatment period. The experiments were repeated at least twice.

Metal analysis

Plants from all the treatments were harvested at the same time, washed thoroughly with distilled deionized water, and divided into root and shoot biomass. Metal from the entire biomass was extracted using the closed Teflon vessel method as described by Topper and Kotuby-Amacher (1990). Briefly, the tissue was cut into small pieces and oven dried at $80{ }^{\circ} \mathrm{C}$ for 2 days. Oven-dried materials were weighted, and a sample of $1 \mathrm{~g}$ each was placed in Teflon vessels. The plant material was digested by adding $30 \mathrm{~mL}$ of trace metal grade nitric acid (70\%, Merck), and the Teflon vessels were placed in an oven overnight $\left(110^{\circ} \mathrm{C}\right)$. The metal content in the extract was estimated using a flame atomic absorption spectrophotometer, Model PerkinsElmer. Standard solutions were used to assess the concentrations of samples.

Statistical analysis

Analysis of variance (one-way ANOVA) was carried out using the Statistical software, SPSS, 11 to determinate if there were significant differences in metal accumulation as a result of metal treatments. Significant differences between the means assessed by Duncan test at $P<0.05$.

\section{Results}

Exposure of scented geraniums to various concentrations of $\mathrm{Ni}, \mathrm{Cd}$, or $\mathrm{Pb}$ induced morphotoxicity symptoms on the plants exposed to the higher levels (Fig. 1). 

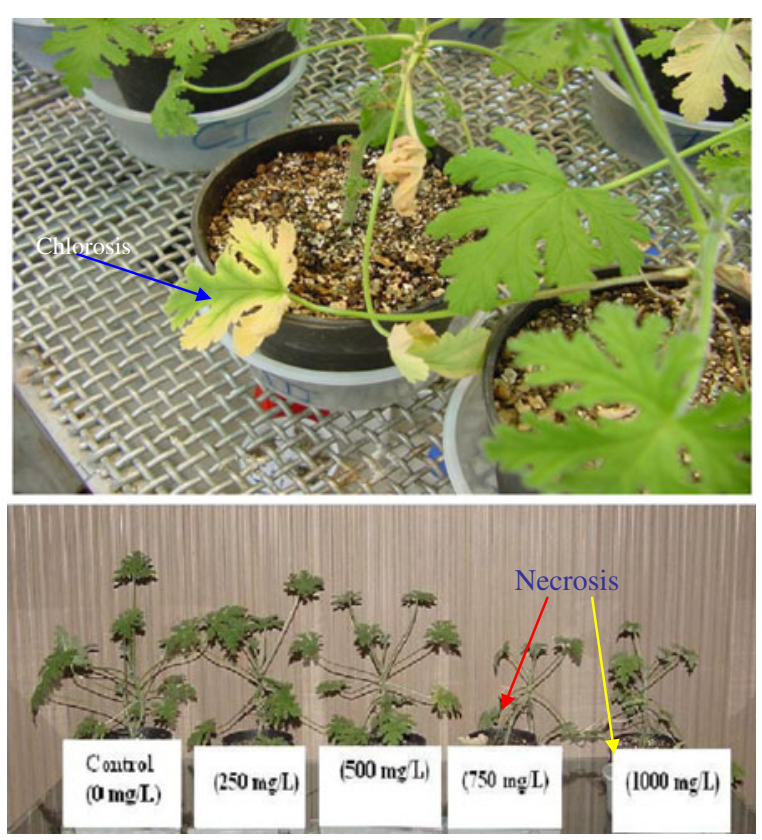

Fig. 1 Morpho-phytotoxicity symptoms in scented geranium plants, following exposure to $750-1,000 \mathrm{mgL}^{-1} \mathrm{Ni}\left(\mathrm{NO}_{3}\right)_{2} \cdot 4 \mathrm{H}_{2} \mathrm{O}$ or $\mathrm{Cd}\left(\mathrm{NO}_{3}\right)_{2} \cdot 4 \mathrm{H}_{2} \mathrm{O}$ for 14 days

The symptoms were mostly observed on the mature leaves (at 12 days), which indicated signs of chlorosis and early senescence. In addition, these plants were shorter than control plants (Fig. 1).

The uptake and accumulation of nickel in roots of scented geranium plants increased with the exposure at low $\left(250,500 \mathrm{mgL}^{-1}\right)$ and medium level $\left(750 \mathrm{mgL}^{-1}\right)$ followed by a decline at the highest level $\left(1,000 \mathrm{mgL}^{-1}\right)$. The highest accumulation in roots $\left(20,055 \mathrm{mg} \mathrm{kg}^{-1} \mathrm{DW}\right)$ was observed in the medium (750 $\mathrm{mgL}^{-1}$ ) nickel treatment (Fig. 2a).

In the shoots of scented geraniums at the low levels of nickel exposure, the amount of metal accumulated reached 882 and $5,649 \mathrm{mgkg}^{-1} \mathrm{DW}$. The highest amount of metal accumulation $\left(10,889 \mathrm{mgkg}^{-1} \mathrm{DW}\right)$ was detected at 750 and followed by a decline at the highest level $\left(1,000 \mathrm{mgL}^{-1}\right)$ of nickel in the culture solution (Fig. 2b).

The results of this research showed that the uptake and accumulation of lead $(\mathrm{Pb})$ in shoot and root followed a similar trend (Fig. 3). The highest amount of $\mathrm{Pb}$ accumulation was detected at $2,500 \mathrm{mgL}^{-1}$ lead nitrate in culture solution that was $86,566 \mathrm{mg} \mathrm{kg}^{-1} \mathrm{DW}$ for roots (Fig. 3a) and 4,416 $\mathrm{mg} \mathrm{kg}^{-1} \mathrm{DW}$ for shoots (Fig. 3b).
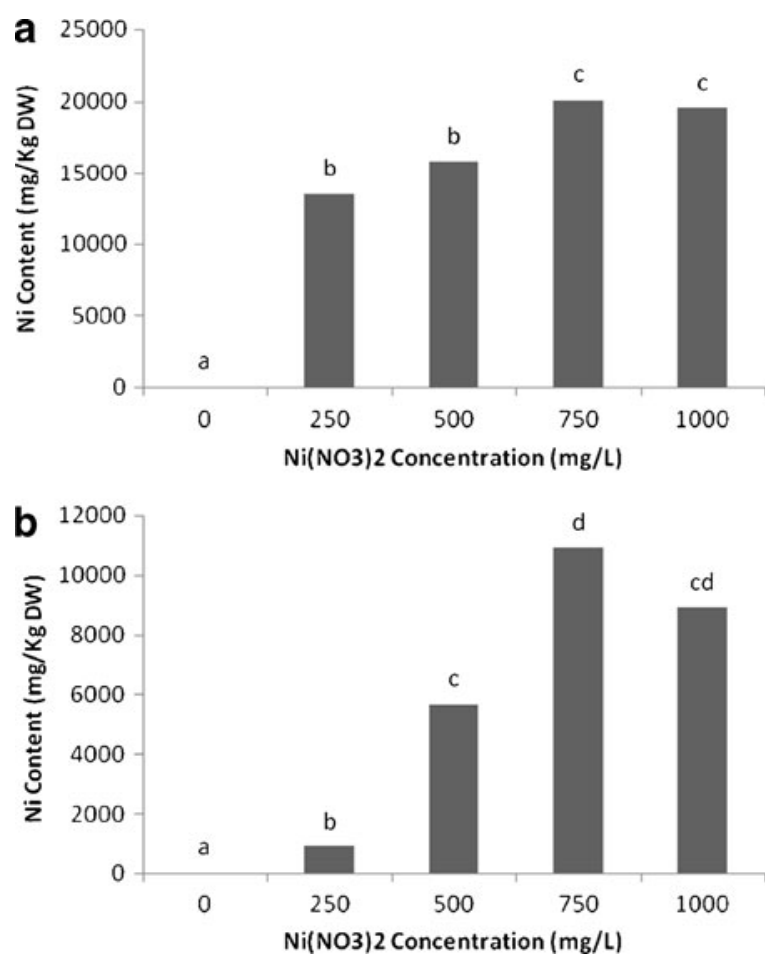

Fig. 2 Nickel content ( $\left.\mathrm{mg} \mathrm{kg}^{-1} \mathrm{DW}\right)$ in roots (a) and shoots (b) of scented geranium plants (Pelargonium roseum), exposed to various levels of Ni for 14 days. All the values are mean of three replicates \pm SD. Different letters show significant differences at $P<0.05$ (one-way ANOVA, Duncan test)

In the case of cadmium, results showed that the uptake and accumulation of this heavy metal in roots of scented geranium plants increased with the exposure at low (250, $\left.500 \mathrm{mgL}^{-1}\right)$ and medium level $\left(750 \mathrm{mgL}^{-1}\right)$ followed by a decline at the highest level $\left(1,000 \mathrm{mgL}^{-1}\right)$ (Fig. 4a). The highest accumulation in roots $\left(31,267 \mathrm{mgkg}^{-1} \mathrm{DW}\right)$ was observed in $750 \mathrm{mgL}^{-1}$ cadmium treatment (Fig. 4a).

In the shoots of scented geraniums, the highest amount of metal accumulation $\left(1,957 \mathrm{mgkg}^{-1} \mathrm{DW}\right)$ was detected at 750 and $1,000 \mathrm{mgL}^{-1}$ of cadmium in the culture solution (Fig. 4b).

\section{Discussion}

Phytoremediation of heavy metals has gained a lot of attention in last decades (Reeves and Baker 2000). Plants vary in their ability to remediate and uptake heavy metals. For efficient phytoremediation, screening and selection of hyperaccumulator plants especially for important heavy metals like $\mathrm{Pb}, \mathrm{Cd}$, and $\mathrm{Ni}$ are 

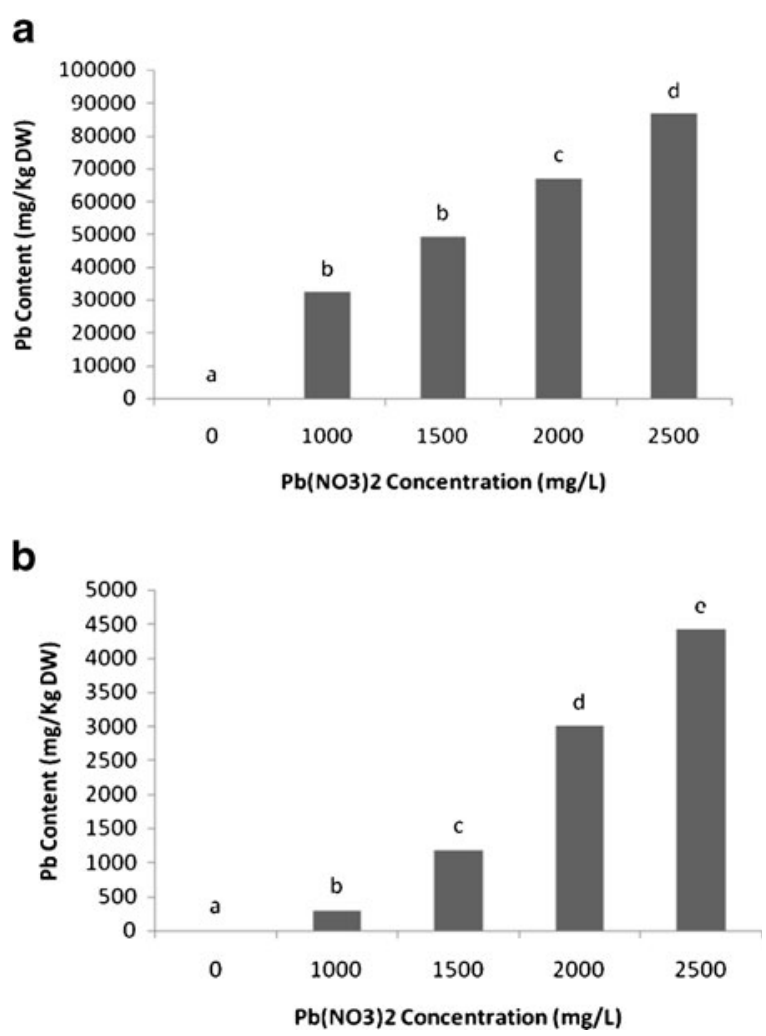

Fig. 3 Lead $(\mathrm{Pb})$ content $\left(\mathrm{mgkg}^{-1} \mathrm{DW}\right)$ in roots (a) and shoots (b) of scented geranium plants (Pelargonium roseum), exposed to various levels of $\mathrm{Pb}$ for 14 days. All the values are mean of three replicates \pm SD. Different letters show significant differences at $P<0.05$ (one-way ANOVA, Duncan test)

necessary. Thus, identification of new plant species with a high biomass and a robust growth habit, coupled with ability to tolerate and accumulate multiple metals, has become an important aspect of phytoremediation.

Pelargonium roseum is a fragrance and ornamental plant and grows on wide geographical locations in world. In this study, we showed its high efficiency for remediation of $\mathrm{Pb}, \mathrm{Ni}$, and $\mathrm{Cd}$ heavy metals. The high concentration of $\mathrm{Ni}$ and $\mathrm{Pb}$ found in the shoots of scented geranium plants has far exceeded $0.1 \%$ DW and $0.01 \%$ for $\mathrm{Cd}$ which are considered as a standard for defining $\mathrm{Ni}, \mathrm{Pb}$, or $\mathrm{Cd}$ hyperaccumulator plants in a natural environment (Chaney et al. 1997), and it is likely be a new hyperaccumulator plant.

The linear pattern of uptake in this plant suggests the involvement of both active and passive transport mechanisms for lead uptake.

The higher metals content found in the roots of metal accumulators is highly dependent on at least two components, namely: sequestration and/or translocation.
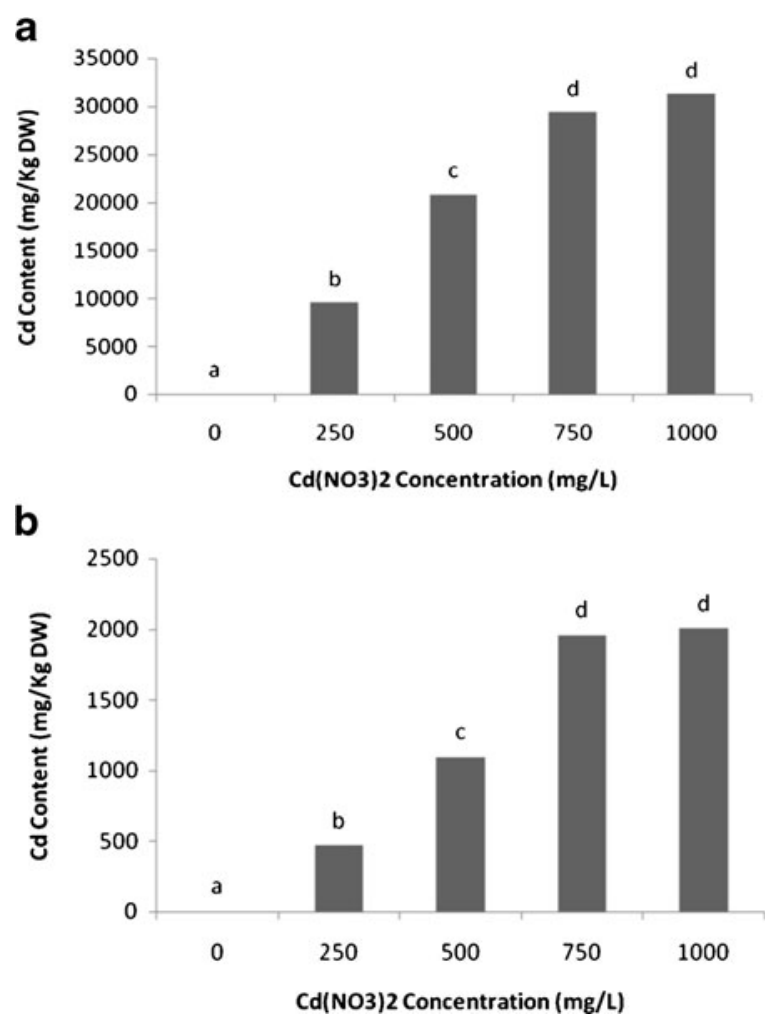

Fig. 4 Cadmium (Cd) content $\left(\mathrm{mgkg}^{-1} \mathrm{DW}\right)$ in roots (a) and shoots (b) of scented geranium plants (Pelargonium roseum), exposed to various levels of Cd for 14 days. All the values are mean of three replicates \pm SD. Different letters show significant differences at $P<0.05$ (one-way ANOVA, Duncan test)

Nickel and cadmium sequestration in roots has been associated with the formation of cell wall ingrowths (Vasquez et al. 1992), precipitation of metal oxalates in root intercellular spaces (Van Balen et al. 1980), and apoplastic storage (Vasquez et al. 1992). Alternatively, nickel and cadmium binding to low molecular weight peptides and proteins (Weigel and Jager 1980) has also been suggested to be involved in metal sequestration in roots. Metal transport to the shoot primarily takes place through the xylem. The metal loading into the xylem sap of Brassica juncea displays biphasic saturation kinetics (Salt et al. 1995), suggesting that xylem loading of metal ions is facilitated by specialized membrane transport processes. Movement of metal ions, particularly cadmium, in xylem vessels appears to be mainly dependent on transpiration-driven mass flow (Salt et al. 1995).

Because xylem cell walls have a high cation exchange capacity, they are expected to retard severely the upward movement of metal cations. Therefore, non cationic metal-chelate complexes, such as nickel-citrate, should 
be transported more efficiently in transpiration stream (Senden et al. 1990). Theoretical studies have predicted that the majority of the Fe (II) and Zn (II) in xylem sap should be chelated by citrate, whereas Ni (II) should be chelated by various amino acids including histidine and asparagines (Senden et al. 1990). Isolation of a citrate nickelate (II) complex from the latex of the $\mathrm{Ni}$ hyperaccumulator Serbertia acuminata supports the role of organic acids in metal transport (Lee et al. 1977).

X-ray absorbance fine structure (EXAFS) analysis showed that $\mathrm{Cd}$ in xylem sap of $B$. juncea was chelated by oxygen or nitrogen atoms, suggesting the involvement of organic acids in nickel translocation (Salt et al. 1995). EXAFS analysis produced no evidence for sulfur coordination of nickel, confirming that phytochelatins and other thiol-containing ligands play no direct role in nickel transport in the xylem.

\section{Conclusion}

In the present investigation, we have demonstrated the high potential of scented geranium for uptake and accumulation of heavy metals. This along with earlier reports on lead accumulation in scented geranium plants (KrishnaRaj et al. 2000) indicates the efficacy of different species of this genus for decontamination of multiple metal-polluted sites in phytoremediation industry.

Acknowledgments This research was supported by a grant (no. 13825) from Arak University.

Open Access This article is distributed under the terms of the Creative Commons Attribution License which permits any use, distribution, and reproduction in any medium, provided the original author(s) and the source are credited.

\section{References}

Baker, A. J. M., Reeves, R. D., \& Hajar, A. S. M. (1994). Heavy metal accumulation and tolerance in British populations of the metallophyte Thlaspi caerulescens J. and Pres1 (Brassicaceae). New Phytology, 127, 61-68.
Chaney, R. L., Malik, M., Li, Y. M., Brown, S. L., Brewer, E. P., Angle, J. S., et al. (1997). Phytoremediation of soil metals. Current Opinion in Biotechnology, 8, 279284.

Gleba, D., Borisjuk, N. V., Borisjuk, L., Kneer, R., Poulev, A., Skarzhiskaya, M., et al. (1999). Use of plant roots for phytoremediation and molecular farming. Proceedings of the National Academy of Science, 96, 5973-5977.

Hoagland, D. R., \& Arnon, D. I. (1950). The water culture method for growing plants without soil. Circular California Agricultural Experiment Station, 347, 1-32.

KrishnaRaj, S., Dan, T. V., \& Saxena, P. (2000). A fragrant solution to soil remediation. International Journal of Phytoremediation, 2, 117-132.

Lee, J., Reeves, R. D., Brooks, R. R., \& Jaffre, T. (1977). Isolation and identification of citro-complex of nickel from nickel accumulating plants. Phytochemistry, 16, 15031505.

Luo, Y. M. (2009). Current research and development in soil remediation technologies. Progress in Chemistry, 21, 558565.

Reeves, R. D., \& Baker, A. J. M. (2000). Metal accumulating plants. In I. Raskin \& B. D. Ensley (Eds.), Phytoremediation of toxic metals: Using plants to cleanup the environment (pp. 193-230). New York: John Wiley and Sons.

Salt, D. E., Prince, R. C., Pickering, I. J., \& Raskin, I. (1995). Mechanisms of cadmium mobility and accumulation in Indian mustard. Plant Physiology, 109, 1427-1433.

Senden, M. H., Van Paassen, F. J. M., Van der Meer, A. J. G. M., \& Wolterbeek, H. (1990). Nickel-citric acid-xylem cell wall interactions in tomato plants. Plant, Cell \& Environment, 15, 71-79.

Topper, K., \& Kotuby-Amacher, J. (1990). Evaluation of a closed vessel acid digestion method for plants analyses using inductively coupled plasma spectrometry. Communications in Soil Science and Plant Analysis, 21, 1437-1455.

Van Balen, E., Van de Geijn, S. C., \& Desmet, G. M. (1980). Autoradiographic evidence for the incorporation of cadmium into calcium oxalate crystals. Zeitschrift für Pflanzenphysiologie, 97, 123-133.

Vasquez, M. D., Poschenrieder, C. H., \& Barceld, Y. (1992). Cadmium in bean roots. New Phytology, 120, 215-226.

Vasquez, M. D., Barceld, Y., Poschenrieder, C. H., Madico, J., Hatton, P., Baker, A., et al. (1992). Localization of zinc and nickel in Thlaspi caerulescens (Brassicaceae), a metallophyte that can hyperaccumulate both metals. Journal of Plant Physiology, 40, 350-355.

Weigel, H., \& Jager, H. (1980). Subcellular distribution and chemical from of nickel in bean plants. Plant Physiology, $65,480-482$. 